Board of Governors of the Federal Reserve System

\author{
International Finance Discussion Papers
}

Number 753

January 2003

\title{
Firm-Level Access To International Capital Markets: \\ Evidence From Chilean Equities
}

\author{
Sara B. Holland and Francis E. Warnock
}

NOTE: International Finance Discussion Papers are preliminary materials circulated to stimulate discussion and critical comment. References in publications to International Finance Discussion Papers (other than an acknowledgment that the writer has had access to unpublished material) should be cleared with the author or authors. Recent IFDPs are available on the Web at www.federalreserve.gov/pubs/ifdp/. 


\title{
Firm-Level Access To International Capital Markets: Evidence From Chilean Equities
}

Sara B. Holland and Francis E. Warnock ${ }^{\star}$

\begin{abstract}
High growth, liquid Chilean firms have greater relative weights in U.S. equity portfolios, but the most important determinant of a firm's portfolio weight is whether it is listed on a U.S. exchange. Crosslisting does not, however, appear to have permanent benefits: Weights in U.S. portfolios of firms that crosslisted in the mid-1990s increased at the expense of firms that cross-listed earlier. Put another way, firms appear to be able to access international capital at the time of the cross-listing, but this access may well be short-lived.
\end{abstract}

Keywords: financial liberalization, portfolio choice, emerging market, home bias

JEL Classification: G1, G3, F3

* The authors are, respectively, Research Assistant and Economist in the International Finance Division of the Board of Governors of the Federal Reserve System. E-mail addresses: sara.b.holland@frb.gov, frank.warnock@frb.gov. The authors thank William Griever and two anonymous referees for helpful comments. We also thank Alka Banerjee of Standard and Poor's for helping us with the S\&P/IFC data. All errors are our own. The views in this paper are solely the responsibility of the authors and should not be interpreted as reflecting the views of the Board of Governors of the Federal Reserve System or of any other person associated with the Federal Reserve System. The statistical analysis of security-level data on U.S. investors' holdings reported in this study was conducted at the International Finance Division of the Board of Governors of the Federal Reserve System under arrangements that maintained legal confidentiality requirements. 


\section{Introduction}

A wide and growing literature has documented the effects of financial market liberalization. Though debates are ongoing, evidence now suggests that when emerging markets liberalize they experience capital inflows, an investment boom, increased growth, and a decrease in the cost of capital (Bekaert and Harvey (2000), Henry (2000a, 2000b), Kim and Singal (2000), Edison and Warnock (forthcoming), Bekaert, Harvey, and Lundblad (2002)). A still outstanding question, however, is whether these effects are countrywide or firm-specific. For example, after a country liberalizes its financial markets, is the average firm able to access international capital markets, or is international capital only available to certain firms? ${ }^{1}$

We address these questions by focusing on a narrow group of firms and a narrow but important group of global investors. Specifically, we analyze high quality survey data on U.S. investors' holdings of individual Chilean equities. The firm-level holdings data allow us to identify the roles of firm characteristics that influence weights in U.S. portfolios. And, because the surveys were conducted as of two points in time, we are able to analyze the evolution of those portfolio weights.

Studies have examined the effects of firm characteristics on foreigners' portfolios in industrial countries. For example, it is apparent from the work of Kang and Stulz(1997), henceforth KS, and Dahlquist and Robertsson (2001), henceforth DR, that in industrial countries foreigners overweight large firms and firms that produce internationally traded goods, possibly because investors possess more information about such firms.

Our results suggest that while some aspects of these previous findings apply to emerging markets, there are also important differences. For example, as in previous studies, we find

${ }^{1}$ See Chari and Henry (2001, 2002a, and 2002b) for analyses of firm-level returns and capital stocks after a liberalization. 
that investors prefer liquid, high growth firms. However, characteristics that are related to the amount of readily available firm-level information — size and producing an internationally traded good - do not appear to influence U.S. investors' decisions in Chile. Indeed, we find that firms that produce internationally traded goods are underweighted relative to those that produce non-traded goods.

Our more important findings concern the effects of international cross listings on portfolio weights and the implications for the breadth (widespread or firm-specific) of access to international capital markets. It is by now well known that cross listings, because they often involve opting into stricter regulatory environments, have an important information content (Coffee (1999), Stulz (1999), Doidge, Karolyi, and Stulz (2001), Lang, Lins, and Miller (forthcoming)). Our results are consistent with these findings: The most important determinant of a firm's weight in U.S. portfolios is whether it is listed on a U.S. exchange and hence subject to U.S. investor protection regulations. But we go a step further by examining the evolution of firms' weights in U.S. portfolios. We find that while the average Chilean firm did not gain a larger share in U.S. portfolios between 1994 and 1997, those firms that cross-listed during that period experienced substantially increased weights in U.S. portfolios. They did so, however, not at the expense of firms that never cross-listed, but of those that had cross-listed prior to 1994. That is, firms that cross-list gain access to international capital, but the access may well be short-lived.

The paper proceeds as follows. In the next section, we describe our sample and provide summary statistics of the main explanatory variables. In Section III, we more formally describe the determinants of firms' weights in U.S. portfolios by presenting results from multivariate regressions, while delving further into the role of cross-listings and questions of the breadth of access to international capital. Section IV concludes. 


\section{U.S. Investors' Chilean Equity Portfolios: Descriptive Statistics}

We use confidential security-level data on U.S. holdings of Chilean stocks from comprehensive benchmark surveys conducted by the U.S. Treasury Department and the Federal Reserve Board as of March 1994 and December 1997. ${ }^{2}$ Data on firm specific characteristics are from Worldscope and Standard \& Poor's Emerging Markets Data Base. ${ }^{3}$

For Chile, the period over which our two observation span was one of strong economic growth, low inflation, and a stable exchange rate. From March 1994 to December 1997, Chilean market capitalization increased over fifty percent to $\$ 72$ billion and the number of companies listed on the Santiago Stock Exchange increased from 268 to 295. Chilean equity prices increased strongly in 1994, but were flat thereafter. Over the inter-survey period, U.S. investors' positions in Chilean equities nearly doubled from $\$ 2.5$ billion to $\$ 4.6$ billion, but because U.S. equity wealth more than doubled, the relative weight of Chilean equities in U.S. portfolios decreased slightly from 0.14 to 0.12 . $^{4}$ This minor shift in the weight of Chilean equities in U.S. portfolios may, however, mask substantial shifts in the weights of individual firms, the main focus of this paper.

That foreign holdings in emerging markets may have different characteristics than holdings in industrial countries is evident in Table 1, which presents U.S. ownership of Chilean equities by industry. Ownership is defined in this table as the ratio of the weight of the firm in U.S.

${ }^{2}$ Publicly available country-level data from the benchmark surveys are presented in Treasury Department and Federal Reserve Board (2000) and analyzed in Ahearne, Griever, and Warnock (forthcoming) and Pinkowitz, Stulz, and Williamson (2001).

${ }^{3}$ We use the May 1999 Worldscope CD in an attempt to get complete coverage for 1997 while minimizing the loss of data due to "dead" companies. portfolio.

${ }^{4}$ Relative weight is the weight in U.S. portfolios relative to the weight in the world 
investors' Chilean equity portfolio to the weight of the firm in the Chilean market. ${ }^{5}$ If investors held shares in proportion to their shares in the Chilean market, the foreign ownership value would be one. Any value less than one indicates an underweighting of that industry; any value over one implies overweighting. KS and DR found that foreign investors tended to overweight industries that produce internationally traded goods - manufacturing in Japan and engineering in Sweden — and underweight "local" or non-tradeable sectors. Table 1, however, suggests that those findings may not apply to emerging markets: In Chile, U.S. investors overweight "local" sectors-transportation, communication, and utilities - and underweight manufacturing. Sectoral weights for 1994 (not shown) follow a similar pattern.

Table 2 presents two indicators of simple bivariate relationships between holdings and firm characteristics: quintile analysis and t-statistics from bivariate regressions. Here, and for the rest of the paper, as in DR foreign ownership is defined as $y_{i}=\omega_{i}{ }^{U S} / \omega_{i}{ }^{M}-1$, which is the ratio of security $i$ 's weight in U.S. equity portfolios to its weight in the world market portfolio, minus one. Hence, a $y$-value of negative one indicates no foreign ownership, the underweighting (or bias) decreases as the value moves closer to zero, and investors overweight equities that have a positive $y$-value.

The characteristics we use are as in KS and DR, as long as Worldscope coverage for Chilean firms was sufficient. ${ }^{6}$ We add one additional variable (the IFC Investable Weight) and

${ }^{5}$ For Table 1, U.S. investors' Chilean equity portfolio and the Chilean market are restricted to firms in the sample.

${ }^{6}$ Due to limitations of the data sources and the nature of examining an emerging market, some data were not available. Most importantly, adequate foreign sales data do not exist for Chilean firms. Although this deficiency could be a shortcoming, especially since DR find this characteristic to have a significant impact on foreign ownership, as shown in Table 1 U.S. investors tend to overweight Chilean firms for which international trade are not important, such as telecommunications and utilities firms. 
adjust another (percent of shares closely held) for errors in the Worldscope database. The attributes we examine include:

(a) Size: Previous studies have shown that both U.S. institutions (Falkenstein (1996) and Gompers and Metrick (2001)) and foreigners (KS and DR) have preferences for larger firms. In the case of foreign investment, one might argue that information asymmetries might be less severe for larger firms, in which case a large firm preference would be consistent with Merton's (1987) model in which investors prefer firms they know. We measure firm size by (log) market capitalization, which comes from the S\&P/IFC EMDB. The quintile analysis in Table 2 indicates that in general the level of bias decreases as firm size increases; the t-statistic indicates that this positive relationship is statistically significant.

(b) Return on assets: Return on assets (ROA) is an accounting performance measure calculated as net income over total assets. If there is persistence in accounting performance, U.S. investors might favor Chilean stocks with high ROA, but, as in KR and DR, we do not find a significant relationship between ROA and U.S. positions.

(c) Debt-to-equity ratio: Debt-to-equity is a leverage ratio generally comprising shortand long-term debt plus the current portion of long term debt over common equity. Firms with higher leverage are more financially vulnerable and, thus, might attract less foreign investment. There does not, however, appear to be a meaningful relationship between bias and this variable.

(d) Current ratio: Current ratio, calculated as current assets over current liabilities, indicates the firm's ability to meet short-term obligations. Firms with a high current ratio are in better financial health (at least in the short-term) and, thus, might be more attractive to foreign investors. DR find that this is indeed true in Sweden, but Table 2 provides no indication that Chilean firms with higher current ratios attract more U.S. investment.

(e) Beta: Beta, which we have calculated beta relative to the global market using 
monthly returns from the Morgan Stanley Capital International index and firm-level returns from the S\&P EMDB, measures the systematic risk of a stock. KS and DR found little evidence that a firm's beta is significantly related to foreign ownership. We see some indication that U.S. investors' prefer Chilean stocks with high systematic risk, in line with the Barber and Odean (2000) result for

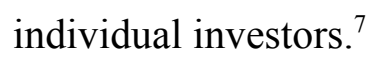

(f) Closely Held: Closely held is the percent of outstanding common shares that are held by insiders. We expect stocks with a high concentration of insiders to have smaller weights in U.S. portfolios for algebraic reasons but also because insiders' objectives might not align with those of atomistic investors. DR find a negative and significant relationship between foreign ownership and ownership concentration, but we find less bias as the percentage of closely held shares increases. This counterintuitive result spurred further investigation into the closely held measure recorded in the Worldscope database, and we found that in our sample Worldscope incorrectly counts the depositary banks that handle ADR programs as major shareholders (see Appendix for details).

(f*) Adjusted Closely Held: Based on the findings presented in the Appendix, we calculate an adjusted closely held variable by subtracting the percentage closely held that Worldscope incorrectly attributes to depositary banks. Using this adjusted closely held figure eliminates the counterintuitive result; bias now tends to increase as firms are more closely held and the negative t-statistic is statistically significant.

(g) Investable weight: The investable weight, which is the basis of the Edison and Warnock (forthcoming) capital controls measure, represents the portion of a firm's equity that is available to a foreign investor. If a stock is fully investable, its weight is 1.00 in the EMDB.

${ }^{7}$ If Chile were not integrated with global markets, beta measured with respect to the local (Chilean) market would be more appropriate. In our sample period, however, it was open to foreign investment and thus more likely integrated than segmented. Furthermore, a local beta is insignificant in bivariate and multivariate regressions. 
Because a large number of Chilean firms in this sample were completely open to foreign investors as of end-1997, the quintile analysis provides little information, but the significant positive t-statistic indicates that foreign ownership increases with investable weight.

(h) Book-to-market ratio: Book-to-market is a stock performance ratio given by the book value per share over the market price at year end. We have no prior on this variable. Low book-to-market "growth" stocks have been shown to be favored by mutual funds (Carhart(1997)), but other evidence suggests that institutional investors prefer high book-to-market "value" stocks (Gompers and Metrick (2001)). In line with results in KS, the quintile rankings and bivariate regression results indicate that U.S. investors prefer Chilean growth stocks.

(i) Turnover: Turnover, calculated as the value of trading in a stock over the previous twelve months (from the EMDB) over its market capitalization, is a measure of the liquidity of a firm's shares. Some investors may be willing to pay a premium for liquidity and, as DR found, the quintiles and t-statistic show that greater liquidity is associated with greater foreign ownership.

(j) Dividend yield: Dividend yield is a stock performance ratio calculated by dividends per share over the market price at year-end. Yield has been used by Del Guercio (1996) as a "prudence" proxy — stocks paying higher yields might be considered safer — and has predictive power for returns (Fama and French (1988), Campbell and Shiller (1988), Harvey (1995)). DR, however, report a negative significant relationship between dividend yield and foreign ownership, as do Gompers and Metrick (2001) for institutions. We do not find conclusive evidence; the quintiles point to a negative relationship, but this is not confirmed by the t-statistic.

\section{The Role of Cross-Listings}

The quintile analysis and bivariate regressions suggest which characteristics will be more important determinants of U.S. holdings of individual Chilean stocks. Because information for all 
characteristics for all firms is limited, only the variables that seem to have the strongest relationship as well as sufficient coverage across firms are included. ${ }^{8}$ This ensures an adequate number of observations for the multivariate regressions. The results are reported in Table 3.

The first regression shows that U.S. investors have higher weights on Chilean firms that are high growth (low book-to-market), open (high investable weight), and liquid (high turnover). As in DR, size, although positively related to foreign ownership in the quintile analysis, does not have a significant impact on foreign ownership in multivariate regressions. When the adjusted closely held variable is included (regression (2)), its coefficient has the expected sign but is not significant and investable weight and turnover lose significance.

The third set of regression results displayed in Table 3 include the effect of cross-listings through a dummy variable that takes a value of one if the firm is listed on a U.S. exchange. ${ }^{9}$ From the perspective of a U.S. investor, the cross-listing lowers direct transactions costs. The Bank of New York states that investing in foreign firms on U.S. exchanges rather than in the underlying security can save investors 10 to 40 bp annually in custodial fees. Moreover, Elkins-McSherry data indicate that transaction costs are lower on the NYSE than on most foreign stock exchanges. But the cross-listing also lowers indirect information costs. For example, to list equity on U.S. exchanges, a foreign firm must reconcile its accounts with U.S. generally accepted accounting principles (GAAP), meet the SEC's stringent disclosure requirements, and subject itself to the associated regulatory burden. Foreign firms that list on a U.S. exchange and thereby opt into the

${ }^{8}$ Beta is significantly related to holdings in Table 2 , but it is never significant in multivariate regressions. Because including it only reduces the number of usable observations without affecting our results, we do not report beta in multivariate regressions.

${ }^{9}$ All of the Chilean firms in our sample that listed on U.S. exchanges did so through Level II or Level III American Depositary Receipt (ADR) programs. See Miller (1999) for a discussion of ADR programs. 
U.S. investor protection environment are more transparent and have higher valuations (Lins, Strickland, and Zenner (2002), Reese and Weisbach (2002), Lang, Lins, and Miller (forthcoming), and Doidge, Karolyi, and Stulz (2001)). Thus, we expect Chilean firms listed on U.S. exchanges to have greater weights in U.S. portfolios.

The U.S.-listed variable is indeed positive and highly significant, consistent with the results of DR, and when it is included all other variables become insignificant. Moreover, we now explain 64 percent of the variation in holdings, up from about 25 percent when the cross-listing variable is not included. To provide context to the coefficient estimate on the cross-listing variable, the average $y$-value for Chilean firms is -0.89 , which implies that U.S. investors held about 5.5 percent of the average firm. ${ }^{10}$ Holding all else constant, a firm that is cross-listed would have a $y$-value that is 0.225 higher, or about -0.67 , which implies U.S. holdings of 16 percent. To put it another way, a firm with the average market capitalization of $\$ 1$ billion would have U.S. investment of $\$ 55$ million if it is not cross-listed, but $\$ 160$ million if it is.

The results in Table 3 prompt a further investigation into the role of cross-listings. In Table 4 we provide information on the types of Chilean firms that list their shares abroad. Saudagaran (1988) shows that size is the most significant determinant in a firm's tendency to list. Pagano, Roell, and Zechner (2002) show in a sample of European firms that cross-listing firms are large, growing, and R\&D intensive and have higher foreign sales and higher turnover. In Table 4, probit results suggests that large, growing Chilean firms list abroad, consistent with previous results.

The results in Tables 3 and 4 suggest that U.S. investors prefer listed Chilean firms and cross-listed Chilean firms are large and growing. While endogenizing the cross-listing decision is

10 To see this, note that from the definition of $y$, the share of a Chilean stock that was held by U.S. investors as of end-1997 equals approximately $0.5^{*}(y+1)$, where 0.5 is the share of the U.S. market in the world market. Thus, if $y=-0.89$, U.S. investors held 0.055 , or 5.5 percent. 
not feasible in this study_doing so properly would require higher frequency accounting and holdings data — we can investigate the determinants of changes between 1994 and 1997 in firms' weights in U.S. investors' portfolios. This approach is, in some sense, a natural experiment; of the nineteen Chilean firms in our sample that have listed on a U.S. exchange, more than half did so between 1994 and 1997.

Table 5 presents the results of a regression on the change in the bias measure due to changes in the explanatory variables between 1994 and 1997. ${ }^{11}$ If a firm listed shares between March 1994 and December 1997, the listing variable is one. The table shows that firms that became larger or more investable did not experience a significant increase in foreign ownership. ${ }^{12}$ On the other hand, firms with increased liquidity (turnover) had a significant increase in foreign ownership.

The second regression shown in Table 5 shows that when the listing variable is included, its effect dominates all other variables. The highly significant coefficient estimate of 0.249 implies that firms that were not cross-listed as of March 1994 but listed by December 1997 saw an increase in the share of U.S. holdings of over 12 percentage points.

Overall, the weights of Chilean firms in U.S. portfolios did not increase from 1994 to 1997, so the sharp increase in the weights associated with firms that cross-listed during that period must have been offset by decreased weights for other firms. The final columns of Table 5 show that this was indeed the case. The increased portfolio weights of firms that cross-listed between 1994 and 1997 were offset by decreased weights, not in those firms that never listed, but by those firms that listed prior to 1994.

${ }^{11}$ The limitations of Worldscope prevent the inclusion of the change in book-to-market ratio in the changes regression.

12 The lack of significance of the change in investable weight owed to an across-theboard increase in investability over this period. 
To view our results another way, the time line of firms' access to international capital appears to be as follows. Chilean firms typically have minuscule relative weights in U.S. investors' portfolios until they cross-list, at which time they experience an inflow of foreign capital. This inflow, however, is not persistent: When subsequent firms cross-list and gain increased weights in U.S. portfolios, they do so at the expense of firms that cross-listed earlier.

\section{Conclusion}

The story that emerges from our analysis of U.S. investors' Chilean equity portfolios is that while growing firms with high liquidity tend to be able to access global capital markets, by far the most important determinant of a firms' weight in international portfolios is whether it has crosslisted on a U.S. exchange. For example, the portion of the average Chilean equity that is held by U.S. investors is only $5.5 \%$ if the stock is not cross-listed, but $16 \%$ if it is. Moreover, the financing acquired via the cross-listing appears to be a one-time event. U.S. investors buy into firms that cross-list, but do not appear to increase their stakes over time. Strikingly, Chilean firms that crosslisted during the 1994 to 1997 period experienced sharply increased weights in U.S. portfolios, not at the expense not of Chilean firms that had never cross-listed, but of those that had cross-listed earlier.

This paper leaves many open questions. The most important one concerns the nature of financial liberalization and access to international markets. When a country liberalizes, are its firms able to tap international savings? Our results suggests that the ability to access international funds is firm-specific and may not be long-lasting. 


\section{References}

Ahearne, A., W. Griever, and F. Warnock, forthcoming. Information Costs and Home Bias: An Analysis of U.S. Holdings of Foreign Equities. Journal of International Economics.

Barber, B., and T. Odean, 2000. Trading is hazardous to your wealth: The Common Stock Investment Performance of Individual Investors. Journal of Finance, 55(2): 773-806.

Bekaert, G., and C.R. Harvey, 2000. Foreign speculators and emerging equity markets. Journal of Finance, 55:565-614.

Bekaert, G., C.R. Harvey, and C. Lundblad, 2002. Does financial liberalization spur growth? working paper.

Campbell, J.Y., and R. Shiller, 1988. Stock Prices, Earnings, and Expected Dividends. Journal of Finance 43(3): 661-76.

Carhart, M., 1997. On persistence in mutual fund performance. Journal of Finance, 52: 57-82.

Chari, A., and P. Henry, 2001. Stock Market Liberalizations and the Repricing of Systematic Risk. NBER Working Paper \#8265.

, 2002a. Capital Account Liberalization: Allocative Efficiency or Animal Spirits? NBER Working Paper \#8908.

NBER Working Paper \#8988.

, 2002b. Risk Sharing and Asset Prices: Evidence from a Natural Experiment.

Coffee, J., 1999. The future as history: The prospects for global convergence in corporate governance and its implications. Northwestern University Law Review, 641-708.

Dahlquist, M., and G. Robertsson, 2001. Direct foreign ownership, institutional investors, and firm characteristics. Journal of Financial Economics, 59:413-440.

Del Guercio, D., 1996. The distorting effect of the prudent-man laws on institutional equity investments. Journal of Financial Economics, 40: 31-62.

Doidge, Karolyi, and Stulz, 2001. Why are foreign firms listed in the U.S. worth more? NBER Working Paper No. 8538.

Edison, H., and F. Warnock, 2001. A Simple Measure of the Intensity of Capital Controls. Federal Reserve Board, International Finance Discussion Paper \#708 (updated September 2002).

Fama, E., and K. French, 1988. Dividend Yields and Expected Stock Returns. Journal of Financial Economics 22, 3-16. 
Gompers, P., and A. Metrick, 2001. Institutional investors and equity prices. Quarterly Journal of Economics 116(1): 229-259.

Harvey, C., 1995. Predictable Risk and Returns in Emerging Markets. Review of Financial Studies 8(3): 773-816.

Henry, P., 2000a. Stock market liberalization, economic reform, and emerging market equity prices. Journal of Finance, 55(2):529-564.

Henry, P., 2000b. Do stock market liberalizations cause investment booms? Journal of Financial Economics, 58:301-334.

Kang, J., and R. Stulz, 1997. Why is there a home bias? An analysis of foreign portfolio equity ownership in Japan. Journal of Financial Economics, 46:3-28.

Kim, E.H., and V. Singal, 2000. Stock Market Openings: Experience of Emerging Economies. Journal of Business, 73(1):25-66.

Lang, M., K. Lins, and D. Miller, forthcoming. ADRs, Analysts, and Accuracy: Does Cross Listing in the U.S. Improve a Firm's Information Environment and Increase Market Value? Journal of Accounting Research.

Merton, R., 1987. A simple model of capital market equilibrium with incomplete information. Journal of Finance, 42: 483-510.

Miller, D., 1999. The market reaction to international cross-listings: evidence from Depositary Receipts. Journal of Financial Economics, 51: 103-123.

Pagano, M., A. Roell, and J. Zechner, 2002. The Geography of Equity Listing: Why Do Companies List Abroad? Journal of Finance, 57(6).

Pinkowitz, L., R. Stulz, and R. Williamson, 2001. Corporate Governance and the Home Bias. NBER Working Paper \#8680.

Saudagaran, S.M., 1988. An empirical study of selected factors influencing the decision to list on foreign stock exchanges. Journal of International Business Studies, 101-127.

Stulz, R., 1999. Globalization of equity markets and the cost of capital. Journal of Applied Corporate Finance, 12:8-25.

Treasury Department and Federal Reserve Board, 2000. United States Holdings of Foreign LongTerm Securities as of December 31, 1997 and December 31, 1999. 
Table 1. Foreign Ownership by Industry, 1997

\begin{tabular}{|l|c|c|}
\hline Industry & Foreign ownership(y*) & $\mathrm{N}$ \\
\hline Manufacturing & 0.84 & 19 \\
$\begin{array}{l}\text { Transportation \& } \\
\text { Communication and Utilities } \\
\begin{array}{l}\text { Trade, Financial, Insurance, } \\
\text { \& Real Estate, and Services }\end{array}\end{array}$ & 1.31 & 13 \\
\hline
\end{tabular}

Table 1 shows foreign ownership by industry for firms that have complete data in Worldscope and the S\&P Emerging Markets Data Base and for industries that contain at least 10 firms. Foreign ownership is defined as $\mathrm{y}_{\mathrm{i}}{ }^{*}=\omega_{\mathrm{i}} \mathrm{US} / \omega_{\mathrm{i}}^{\mathrm{M}}$, the weight of firm $i$ in U.S. investors' Chilean equity portfolios over the weight of firm $i$ in the Chilean equity market. U.S. investors overweight industries if $\mathrm{y}^{*}>1$. 
Table 2. Rankings of Firms Based on Characteristics, 1997

\begin{tabular}{|l|ccccccccc|}
\hline \multicolumn{7}{|c}{} & \multicolumn{7}{c}{ Quintiles } & & & \\
\cline { 2 - 7 } & Q1 & Q2 & Q3 & Q4 & Q5 & Average & t-stat & N \\
\hline Foreign Ownership(y) & -0.99 & -0.80 & -0.93 & -0.90 & -0.82 & -0.89 & $2.06^{* *}$ & 50 \\
Market capitalization & 126 & 345 & 511 & 1029 & 3461 & 1094 & & \\
Foreign Ownership(y) & -0.86 & -0.88 & -0.94 & -0.85 & -0.83 & -0.87 & 0.93 & 41 \\
$\quad$ Return on assets(\%) & 1 & 5 & 8 & 10 & 13 & 7 & & \\
Foreign Ownership(y) & -0.87 & -0.91 & -0.95 & -0.78 & -0.86 & -0.87 & 0.56 & 44 \\
$\quad$ Debt-to-equity & 6.04 & 26.05 & 41.19 & 63.66 & 253.09 & 79.64 & & \\
Foreign Ownership(y) & -0.86 & -0.83 & -0.88 & -0.92 & -0.87 & -0.87 & -0.69 & 40 \\
$\quad$ Current ratio & 0.66 & 1.21 & 1.46 & 1.93 & 4.86 & 2.02 & & \\
Foreign Ownership(y) & -0.95 & -0.88 & -0.86 & -0.93 & -0.87 & -0.90 & $1.75^{*}$ & 44 \\
$\quad$ Beta & -0.04 & 0.45 & 0.77 & 1.00 & 1.36 & 0.69 & & \\
Foreign Ownership(y) & -0.87 & -0.92 & -0.93 & -0.89 & -0.75 & -0.87 & 1.16 & 43 \\
$\quad$ Closely held shares(\%) & 33 & 52 & 65 & 79 & 87 & 63 & & \\
Foreign Ownership(y) & -0.72 & -0.91 & -0.93 & -0.83 & -0.97 & -0.87 & $-2.31^{* *}$ & 43 \\
$\quad$ Closely held adj.(\%) & 24 & 46 & 57 & 65 & 80 & 55 & & \\
Foreign Ownership(y) & -0.97 & -0.90 & -0.86 & & & -0.89 & $1.83^{*}$ & 50 \\
Investable weight & 0.32 & 0.89 & 1.00 & & & 0.84 & & \\
Foreign Ownership(y) & -0.78 & -0.82 & -0.87 & -0.96 & -0.95 & -0.87 & $-3.15^{* * *}$ & 44 \\
Book-to-market & 0.3 & 0.5 & 0.8 & 1.2 & 1.8 & 0.9 & & \\
Foreign Ownership(y) & -0.94 & -0.90 & -0.91 & -0.86 & -0.82 & -0.89 & $1.94^{*}$ & 50 \\
$\quad$ Turnover rate & 0.02 & 0.04 & 0.08 & 0.14 & 0.32 & 0.12 & & \\
Foreign Ownership(y) & -0.77 & -0.89 & -0.88 & -0.87 & -0.90 & -0.86 & -0.91 & 40 \\
$\quad$ Dividend yield & 1.0 & 2.3 & 3.3 & 4.5 & 7.2 & 3.7 & & \\
\hline
\end{tabular}

Table 2 shows the ranking of firms based on several characteristics for 1997. Firms are ranked and sorted into quintiles, and averages of the characteristic and foreign ownership are given for each, as well as the overall average and number of observations. Foreign ownership is defined as $y_{i}=\omega_{i}{ }^{U S} / \omega_{i}{ }^{M}-1$, which is the ratio of firm $i$ 's weight in the U.S. equity portfolio to its weight in the world portfolio, minus one. Also shown are tstatistics from bivariate regressions with foreign ownership as the dependent variable is shown. Market capitalization is in millions of U.S. dollars. Average investable weight is the average of the 1997:06 and 1997:12 weights given a security in the IFC investable index. Market capitalization, investable weight, and turnover rate come from the Emerging Markets Database. All other characteristics are found in the Worldscope database. ${ }^{* * *},{ }^{* *}$, and ${ }^{*}$ indicate significance at the 1,5 , and 10 percent levels, respectively. 
Table 3. Holdings 1997

\begin{tabular}{|lcccc|}
\hline & $(1)$ & $(2)$ & $(3)$ & $(4)$ \\
\hline Book-to-market & $-0.102^{* * *}$ & $-0.102^{* *}$ & -0.021 & -0.023 \\
Weight & $(2.73)$ & $(2.65)$ & $(0.73)$ & $(0.78)$ \\
& $0.136^{*}$ & 0.110 & 0.019 & 0.052 \\
Market capitalization & $(1.84)$ & $(1.26)$ & $(0.31)$ & $(0.95)$ \\
& 0.001 & 0.000 & -0.012 & -0.011 \\
Turnover & $(0.04)$ & $(0.00)$ & $(0.85)$ & $(0.76)$ \\
& $0.304^{*}$ & 0.262 & 0.040 & 0.112 \\
Closely held shares & $(1.89)$ & $(1.53)$ & $(0.32)$ & $(0.93)$ \\
$\quad$ adjusted) & & -0.001 & -0.001 & $(1.21)$ \\
US-listed & & $(0.66)$ & $0.225^{* * *}$ & $0.215^{* * *}$ \\
& & & $(6.48)$ & $(6.11)$ \\
& & & & 44 \\
No. of Observations & 44 & 43 & 43 & 0.62 \\
\hline R-squared & 0.26 & 0.25 & 0.64 & \\
\hline
\end{tabular}

Table 3 presents regression results where the dependent variable is $y_{i}=\omega_{i}^{\mathrm{F}} / \omega_{i}{ }^{\mathrm{M}}-1$, which is the ratio of firm $i$ 's weight in the U.S. equity portfolio to its weight in the world portfolio, minus one. The absolute values of t-statistics are in parentheses. ${ }^{* * *},{ }^{* *}$, and ${ }^{*}$ indicate significance at the 1,5 , and 10 percent levels, respectively. 
Table 4. Cross-Listing Decision 1997

\begin{tabular}{|lcc|}
\hline & $(1)$ & $(2)$ \\
\hline Market capitalization & $0.613^{* *}$ & 0.484 \\
& $(2.11)$ & $(1.51)$ \\
Closely held shares & -0.014 & -0.012 \\
(adjusted) & $(1.00)$ & $(0.89)$ \\
Book-to-market & & $-1.174^{* *}$ \\
& & $(2.08)$ \\
Sales growth & $0.052^{* *}$ & $0.052^{* *}$ \\
& $(2.28)$ & $(2.05)$ \\
& & \\
\hline No. of Observations & 39 & 39 \\
R-squared & 0.32 & 0.42 \\
\hline
\end{tabular}

Table 4 presents results of a probit regression where the dependent variable takes a value of 1 if the firm was cross-listed on a U.S. exchange and 0 , otherwise. The absolute values of t-statistics are in parentheses. ${ }^{* * *}$, ${ }^{* *}$, and ${ }^{*}$ indicate significance at the 1,5 , and 10 percent levels, respectively. 
Table 5. Change between 1994 and 1997

\begin{tabular}{|lccc|}
\hline & $(1)$ & $(2)$ & $(3)$ \\
\hline Weight & 0.033 & 0.077 & 0.095 \\
Market capitalization & $(0.31)$ & $(0.91)$ & $(1.19)$ \\
& 0.050 & -0.014 & -0.021 \\
Turnover & $(1.01)$ & $(0.34)$ & $(0.52)$ \\
& $0.643^{* *}$ & 0.233 & 0.088 \\
US-Listed after 1994 & $(2.34)$ & $(0.95)$ & $(0.37)$ \\
& & $0.242^{* * *}$ & $0.229^{* * *}$ \\
US-Listed before 1994 & & $(4.15)$ & $(4.16)$ \\
& & & $-0.132^{* *}$ \\
No. of Observations & 36 & & $(2.31)$ \\
R-squared & 0.08 & 36 & 36 \\
\hline
\end{tabular}

Table 5 presents the results of a regression of the change in y (defined in Table 3 ) on changes in explanatory variables. The absolute values of $\mathrm{t}$-statistics are in parentheses. ${ }^{* * *},{ }^{* *}$, and ${ }^{*}$ indicate significance at the 1,5 , and 10 percent levels, respectively. 


\section{Appendix: Correcting Worldscope Closely-Held Variable for Depositary Receipts}

Worldscope defines closely held shares to include those held by directors, officers, or immediate family; those shares held in trust, by any other corporation, or pension and benefit plans; and shares held by individuals who own 5\% or more of outstanding shares. Their definition explicitly excludes shares held in a fiduciary nature. However, the table below-which lists all Chilean firms that had exchange-traded (i.e., Level II or Level III) ADRs as of end-1997—clearly shows that Worldscope is erroneously including amounts of underlying shares that have been converted into depository receipts, at least for Chile.

\begin{tabular}{|l|l|c|}
\hline & \multicolumn{2}{|c|}{ Closely Held (\%) } \\
\hline Company Name & Total & o/w Depositary Bank* \\
\hline BANCO DE A. EDWARDS & & 17 \\
\hline BANCO SANTANDER-CHILE S.A. & 75 & n.a. \\
\hline BANCO SANTIAGO & n.a. & 0 \\
\hline CIA DE TELECOMMUNICACIONES DE CHILE SA & 79 & 88 \\
\hline COMPANIA CERVECERIAS UNIDAS SA & 86 & 16 \\
\hline CRISTALERIAS DE CHILE S.A. & 84 & 13 \\
\hline EMBOTELLADORA ANDINA S.A. & 67 & 17 \\
\hline EMPRESA NACIONAL DE ELECTRICIDAD S.A. & 65 & 11 \\
\hline ENERSIS S.A. & 17 & 17 \\
\hline GENER S.A. & 33 & 16 \\
\hline LABORATORIOS CHILE S.A. & 49 & 0 \\
\hline MADECO S.A. & 84 & 22 \\
\hline MASISA S.A. & 87 & 24 \\
\hline PROVIDA ADMIN. FONDOS PENSIONES & 77 & 36 \\
\hline SANTA ISABEL S.A. & 85 & 48 \\
\hline SOCIEDAD QUIMICA Y MINERA DE CHILE S.A. & 42 & 26 \\
\hline TELEX-CHILE S.A. & 87 & 18 \\
\hline VINA CONCHA Y TORO S.A. & 54 & 16 \\
\hline DISTRIBUCION Y SERVICIO D\&S SA & 70 & 15 \\
\hline
\end{tabular}

* Depositary bank is one of the three main depositary banks: Citibank, Bank of New York, or Morgan Guarantee Trust.

A check of the amounts reported as closely held by the depositary banks showed that the are similar to reported amounts of outstanding depository receipts. Chilean firms that do not have Level II or Level III ADRs do not show the same error in the closely held variable.

In our adjusted closely-held variable, we have subtracted the above amounts erroneously attributed to depositary banks. 